The American Journal of Agriculture and Biomedical Engineering (ISSN - 2689-1018)

VOLUME 04 ISSUE 01 Pages: 5-12

SJIF IMPACT FACTOR (2020: 5. 34) (2021: 5 · 554)

OCLC - 1121105746 METADATA IF - 7.125

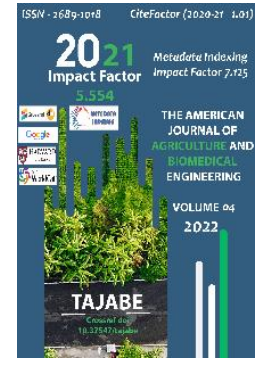

Journal Website: https://theamericanjou rnals.com/index.php/ta jabe

Copyright: Original content from this work may be used under the terms of the creative commons attributes 4.0 licence.
Research Article

\section{DEVELOPMENT OF TECHNOLOGIES FOR PROCESSING SUGAR SORGO, FORMING FEED FOR BEES AND STANDARDS FOR ITS USE}

\author{
Submission Date: January 11, 2021, Accepted Date: January 20, 2022, \\ Published Date: January 30, 2022 | \\ Crossref doi: https://doi.org/10.37547/tajabe/Volume04lssue01-02
}

\author{
Abdurazzakova Mamura Nematjonovna \\ PhD student of Namangan Engineering Technological Institute, Namangan, Uzbekistan \\ Azizov Aktam Sharipovich \\ DSc, Professor of Tashkent State Agrarian University, Tashkent, Uzbekistan
}

\title{
ABSTRACT
}

This article consists of the results of our research concerning creating food for honeybees by recycling the corn stem, which is a crucial and problematic topic for the honey industry of Uzbekistan, and the suggested sorts "O'zbekiston 18", "Qorabosh", and "Oranjovoe 160" meet all the requirements of organic food. It also mentions that the objects of research and juice extraction technology differ considerably from the current alternatives and are created with methods that are efficient and produce no waste. It also mentions the fact that, in out-of-season periods, honeybees consumed the food that was prepared from the juice extracted from different sorts of sweet corn and sugar well, and didn't show any signs of bad side-effects.

\section{KEYWORDS}

Sorghum juice, technological scheme, food for bees, technological processes, beekeeping, diffusion juice.

\section{INTRODUCTION}

Today, the attention and demand for honey products in the countries of the world is growing every year. According to statistics, in 2020, the total volume of honey products produced in the world is 1.85 million tons. Worldwide, the leading producers and exporters of honey products are China (19\%), Argentina (10\%), Ukraine (10\%), Vietnam and India [2]. 
The American Journal of Agriculture and Biomedical Engineering (ISSN - 2689-1018)

VOLUME 04 ISSUE 01 Pages: 5-12

SJIF IMPACT FACTOR (2020: 5. 34) (2021: 5 · 554)

OCLC - 1121105746 METADATA IF - 7.125 cossers (f)

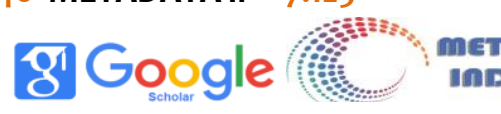

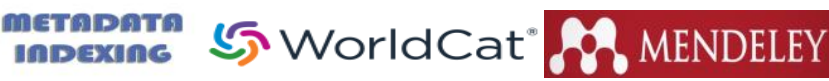

Publisher: The USA Journals

In particular, in our country, great attention is paid to the cultivation of honey. In 2019, Pure Honey Limited Liability Company alone exported 16 tons of honey to the United Arab Emirates. In addition, last year a package of bees worth 700 thousand dollars was delivered to Russia and Kazakhstan. [3].

In recent years, many decrees and resolutions of the President, aimed at accelerating the development of the food industry and providing the population with highquality food, have been adopted. the Decree of the President of the Republic of Uzbekistan dated September 9, 2020 PP-4821 can be one of its examples. For a more effective implementation of the development of the food industry, the Main Directorate for the Development of the Food Industry was created in the structure of the central apparatus of the Ministry of Agriculture.

However, in recent years, the development of beekeeping and honey production all over the world has been declining. According to statistics, it was noted that in 2020 the volume of honey production decreased by 4.7\% compared to 2016 and will keep declining in the future, if appropriate measures are not taken [2]. This, in turn, can lead not only to the inability of the population to meet the demand for honey products, but also to the deterioration of the environment.

The decline in beekeeping all over the world is explained by a number of subjective and objective factors and, most importantly, by a decrease in the size of the food supply for bees.

The availability of food for beekeeping varies depending on the location of the state, climatic conditions. Here are some of them.

For example, in different regions of the Russian Federation, including Perm, Udmurtia, the Chechen Autonomous Republic, Chuvashia, as well as in Ukraine, there is a sufficient natural food base for bees: forests, shrubs and semi-shrubs, medicinal plants, natural landscapes.

In these countries, feeding for bees in gardens, protected forests, ravines and in inconvenient places is created by increasing the area for planting melliferous trees and shrubs and including those melliferous plants in the feed mixture or alternating field crops and increasing the honey yield for a specific zone [3].

In the Udmurt Autonomous Republic in Russia, the range of melliferous plants is very wide. Their value as nectarproducing plants lies in the fact that their flowering coincides with the period of spring growth of bees. There are plants rich in nectar and vitamins, such as black currant, viburnum and meadowsweet, raspberry, alfalfa, annual sunflower, which can be food for bees with high nutritional value [4].

Today, one of the biggest problems in beekeeping in the Republic of Uzbekistan is the lack of off-season feed for bees, that is, in autumn and early spring. And these problems are solved by feeding the bees with sweet water (sugar products in the form of an aqueous mixture).

However, it should be noted that, according to foreign experts, the use of sweet water as a food source for bees is not only insufficient energy value of feed, but also has a negative effect on the viability of bees [5].

Therefore, in recent years, a number of scientists have been conducting research to solve the existing problems of beekeeping in the country.

Makhamadiyarov, one of the scientists conducting research, was first to use wheat -grown in the climatic conditions of Uzbekistan, and its juice, processed in a herbaceous state- as a natural food for bees [6]. 
The American Journal of Agriculture and Biomedical Engineering (ISSN - 2689-1018)

VOLUME 04 ISSUE 01 Pages: 5-12

SJIF IMPACT FACTOR (2020: 5. 34) (2021: 5 · 554)

OCLC - 1121105746 METADATA IF - 7.125
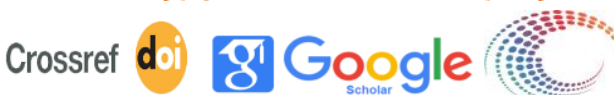

metapenta

5. WorldCat fิ $^{\circ}$ MENDELEY

Publisher: The USA Journals

However, this developed natural feed does not meet the nutritional needs across the country and the production of new types of feed remains an urgent problem.

To partially solve the above problems, we are conducting research on the development of environmentally friendly and natural food products suitable for the climatic conditions of the Republic of Uzbekistan.

The presence in the country of varieties of sweet corn adapted to local conditions is characterized by the fact that the agricultural technologies of their cultivation have been sufficiently studied and new selection varieties have been developed. Another advantage of this plant is its resistance to the climatic conditions of the republic, that is, high temperature, water deficit and different levels of soil salinity, as well as other environmental benefits [7].

A number of scientific studies have been carried out in the country on the processing of sugar sorghum and its use for various purposes.

A. Sh. Azizov developed a technology for producing bioethanol fuel - a renewable energy source from stem juice obtained by processing and pressing the stem of a plant, the parameters of which are scientifically substantiated. The study showed the possibility of growing sugar sorghum on soils with different levels of salinity and in areas of the country with a lack of water [7].

$\mathrm{N}$. Muminov's research is based on the technology of production of pectin and sugar substances, including glucoside-fructose syrup, and sugar substitutes for the food industry by processing various varieties of sugar sorghum, and their parameters are scientifically substantiated [8].

In the research of R. Mirzaev, experiments were carried out to create a raw material base for the production of feed for animal husbandry from the processing waste of various varieties of corn grown in the country [9].

However, at the same time, no studies were carried out in the republic on the use of processed juice of sugar sorghum stalks as feed in beekeeping.

\section{PURPOSE OF THE RESEARCH}

The purpose of our research is to scientifically substantiate the methods of processing the varieties of sugar sorghum "Uzbekistan 18", "Korabosh" and "Oranjevoye-160" by extracting juice from their stem and using them as food for bees.

\section{RESEARCH METHODS AND MATERIALS}

A technological scheme, that differs from the previous research works, was developed (Fig. 1).

According to the developed technological scheme, the varieties of sugar sorghum "Uzbekistan-18", "Korabosh", "Oranjevoye-160" were selected and the technology of their processing and juice extraction was carried out in two directions: the first method, the diffusion process. At the second method, the juice from the stem was separated using screw presses. In this case:

- The sequence of technological processes of the first stage includes: primary processing of the sugar sorghum plant, i.e. the sugar sorghum plant is divided into three components: the stem of the plant, the leaf and part of the rhizome; part of the separated leaves and stems of plants is sent for processing to feed livestock, and part of the stem is transferred to the next stage

- In the next step, the stalks of the sugar sorghum are transferred to the cutting process to cut to a specific and scientifically sound length; cut off sorghum stalks are placed in special containers and placed in different sizes. 
The American Journal of Agriculture and Biomedical Engineering (ISSN - 2689-1018)

VOLUME 04 ISSUE 01 Pages: 5-12

SJIF IMPACT FACTOR (2020: 5 · 34) (2021: 5. 554)

OCLC - 1121105746 METADATA IF - 7.125

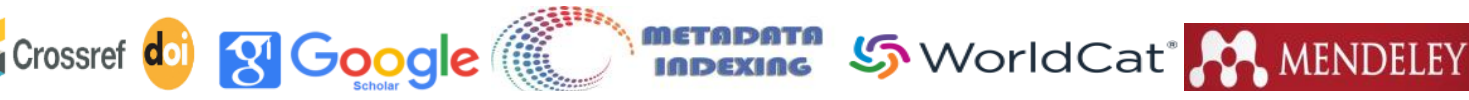

Figure 1. Technological scheme of obtaining juice from sugar sorghum

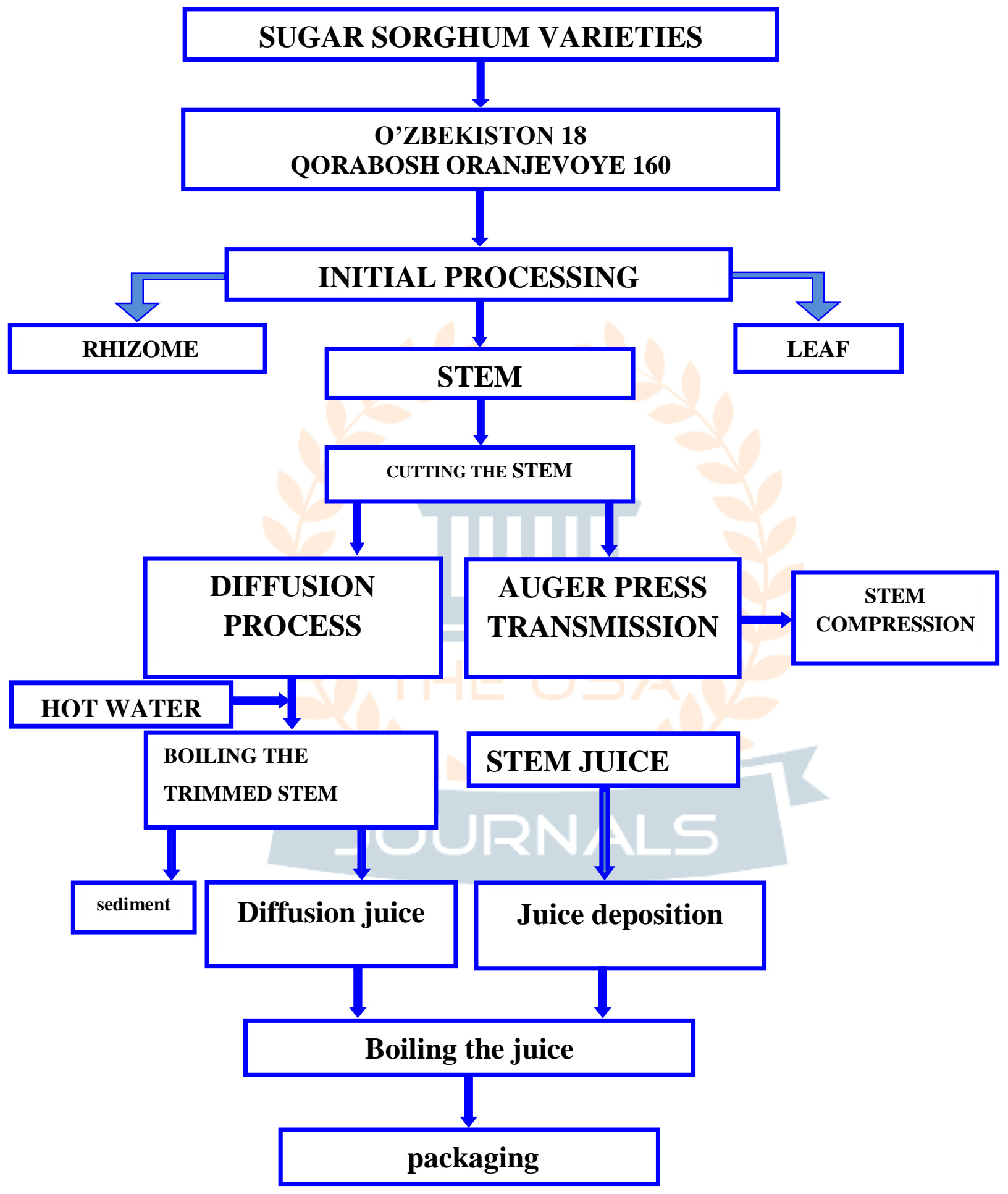


The American Journal of Agriculture and Biomedical Engineering (ISSN - 2689-1018)

VOLUME 04 ISSUE 01 Pages: 5-12

SJIF IMPACT FACTOR (2020: 5. 34) (2021: 5. 554)

OCLC - 1121105746 METADATA IF - 7.125

\section{Crossref doi 81 Google re}

In the next step, the stalks of the sugar sorghum are transferred to the cutting process to cut to a specific and scientifically sound length; cut off sorghum stalks are placed in special containers and placed in different sizes. The next stage of our research is the use of juice obtained from the processing of stalks of sugar sorghum varieties "Uzbekistan 18", "Karabosh" and "Orangevoye 160 " as food for bees.

Experimental work was carried out on 3 different varieties of sugar sorghum, selected as the object of our scientific research. During a study in AugustSeptember 2020-2021, the stalks of sugar sorghum were processed and the samples packed in glass jars were mixed with sugar syrup prepared for bees (one liter of water, one kilogram of sugar) and the bees were fed in varying amounts.

Picture 1. The process of mixing sorghum juice with sugar syrup and preparing bee feed

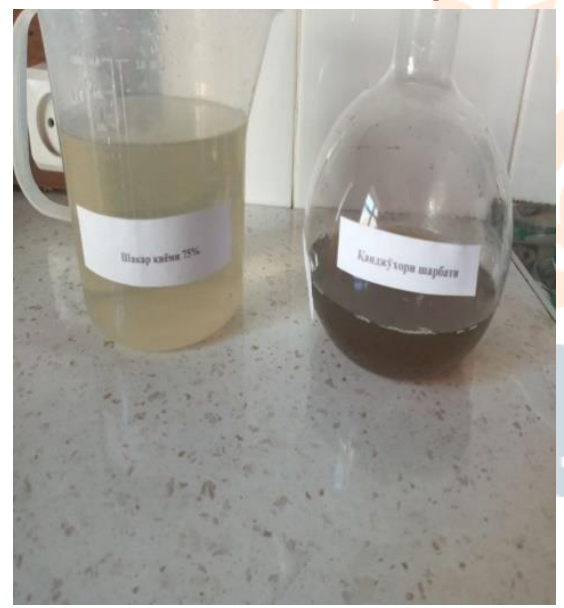

a) juice of sugar sorghum and $75 \%$ sugar syrup

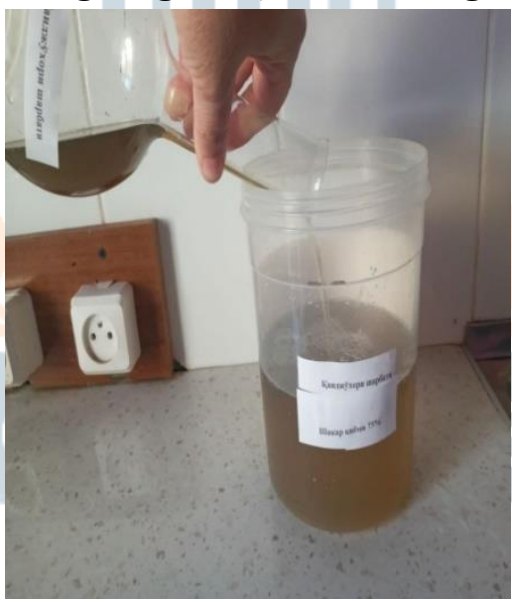

b) the process of mixing sorghum juice with sugar syrup

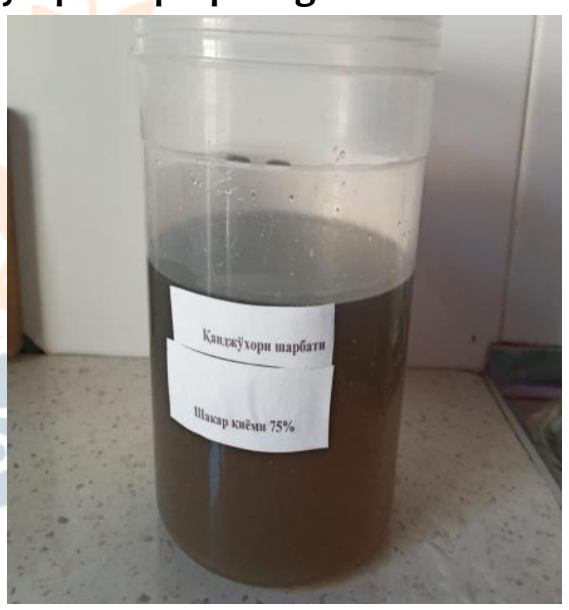

c) sample of the mixed sorghum juice and sugar syrup 
The American Journal of Agriculture and Biomedical Engineering (ISSN - 2689-1018)

VOLUME 04 ISSUE 01 Pages: 5-12

SJIF IMPACT FACTOR (2020: 5· 34) (2021: 5. 554)

OCLC - 1121105746 METADATA IF - 7.125

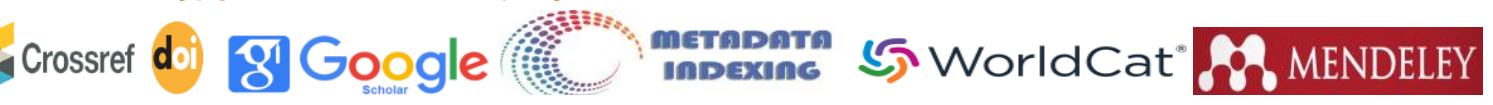

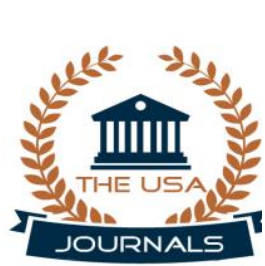

Picture 2.The process of feeding the bees with the mixture of sugar syrup and the juice of sugar sprghum

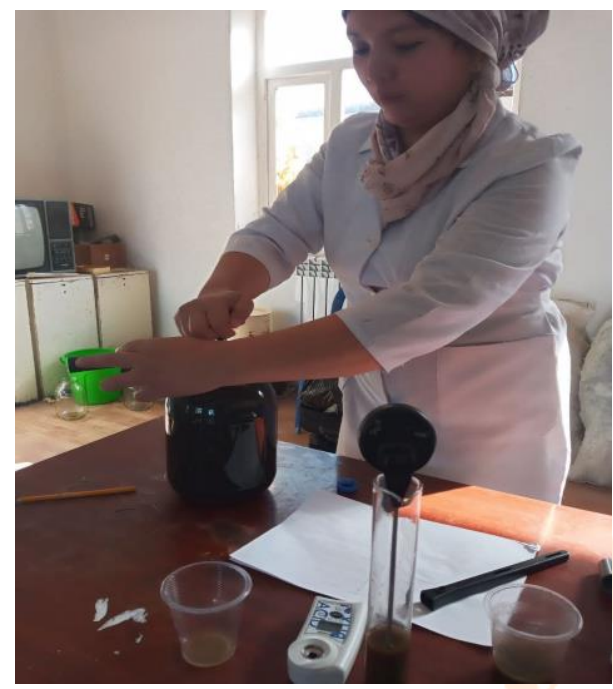

a) the process of packaging the sorghum juice into glass jars
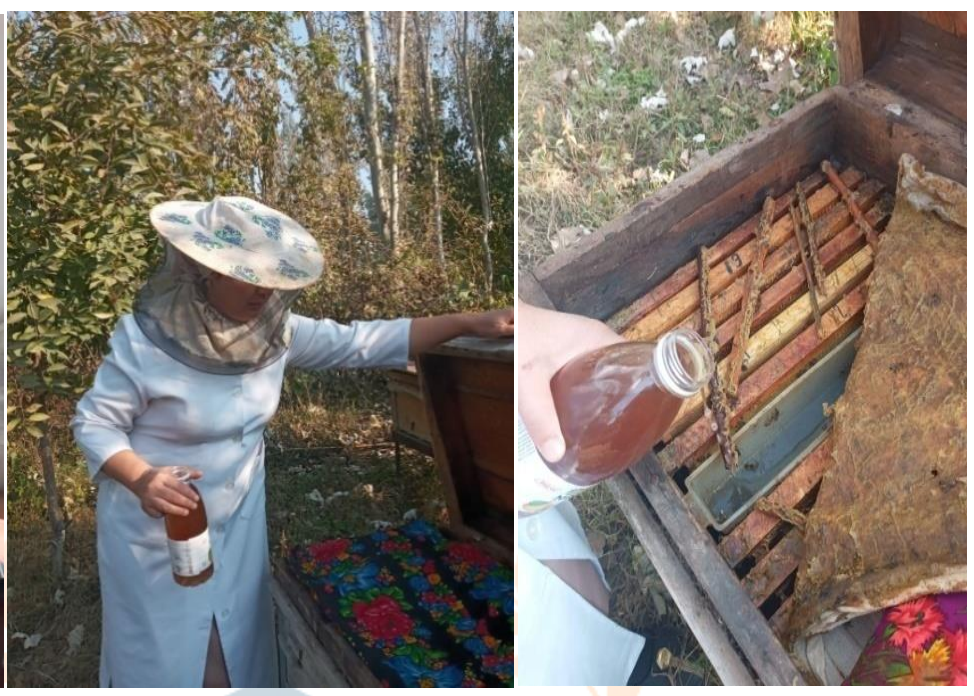

b) The process of feeding the bees with juice
In the course of the experiments, the prepared nutrients were fed in the following order. Sugar sorghum juice, packaged in glass jars, was studied by giving to bee colonies in the second half of September, early October and in the first half of February and March, depending on the weather.

Table 1

Criteria for the preparation of feed from sugar syrup and sugar sorghum juice

\begin{tabular}{|c|c|c|c|c|}
\hline $\begin{array}{c}\text { Number of } \\
\text { samples }\end{array}$ & $\begin{array}{c}\text { Control } \\
\text { liter }\end{array}$ & $\begin{array}{c}\text { Sugar } \\
\text { syrup\% }\end{array}$ & Sugar sorghum juice \% & $\begin{array}{c}\text { Feed preparation } \\
\text { temperature }{ }^{\circ} \mathbf{C}\end{array}$ \\
\hline Sample 1 & 5 & 90 & 10 & 35 \\
\hline Sample 2 & 5 & 80 & 20 & 35 \\
\hline Sample 3 & 5 & 70 & 30 & 35 \\
\hline
\end{tabular}

It can be seen from the table that the feed samples are mainly mixed in 3 different quantities, as a control, the prepared sugar syrup was initially mixed in quantities of 10,20 and $30 \%$ in relation to the amount of syrup.

For experiments with mixed fodders, bee colonies were selected in 4 boxes. At the next stage, the 1st control unit of the selected bees was fed with pure sugar syrup, the 2nd unit with (90\% sugar syrup and 10\% sorghum juice), the 3 rd unit with( $80 \%$ sugar syrup and $20 \%$ sorghum juice), the 4 th unit was fed with(70\% sugar syrup and $30 \%$ sorghum juice) 
The American Journal of Agriculture and Biomedical Engineering (ISSN - 2689-1018)

VOLUME 04 ISSUE 01 Pages: 5-12

SJIF IMPACT FACTOR (2020: 5. 34) (2021: 5. 554)

OCLC - 1121105746 METADATA IF - 7.125

coseses (d)

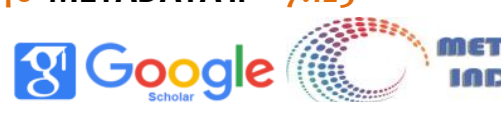

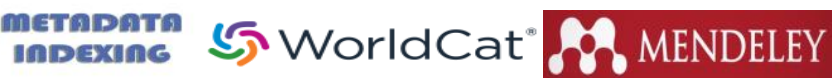

Publisher: The USA Journals

Another goal of our study is to study the consumption of food prepared for bees. In the course of research experiments, the following results were obtained. Samples of sorghum stem juice and sugar syrup mixtures prepared for bees and offered as organic feed were completely consumed by bees and no side effects related to bee health were observed.

\section{RESEARCH RESULTS AND THEIR DISCUSSION}

Our study revealed the need to create additional new sources of organic feed for beekeeping in the republic. At the same time, it was proved that a new source of feed should be environmentally friendly, resource efficient, moreover the proposed varieties of sugar sorghum "Uzbekistan 18", "Karabosh" and "Orange 160 »could meet all the requirements. In addition, the proposed research facility was efficient and waste-free technology, in contrast to existing analogues of juice extraction technology. It was found to be well consumed by the bees and no side effects were observed as a result

\section{CONCLUSION}

Thus, the research results show that the production of stem juice obtained by processing different varieties of sugar sorghum is considered promising not only as an additional source of feed for bees in the off-season, but also because it is a safe, environmentally friendly, waste-free and economical food source for the bee colony.

\section{REFERENCES}

1. Ўзбекистон республикаси Президентининг 2020 йил 9сентябрдаги “ Республика озиқ-овқат саноатини жадал ривожлантириш хамда ахолини сифатли озиқ-овқат махсулотлари билан тўла қонли таъминлашга доир чоратадбирлар тўғрисида”Пқ-4821-сонли қарори
2. М.А.Юдахина Пчеловодство Методические указания Электронное издание Красноярск 2016

3. Г.Ф.Таранов.Корма и кормление пчел. Издание второе переработанное и дополненное. 94,95 CT.

4. Махмадияров Отабек Ахаткулович "Ўзбекистонда асалариларнинг махсулдорлигини оширишда табиий ва минерал озуқалардан фойдаланиш технологиясини такомиллаштириш” (авторефарат 6б).

5. Азизов А.Ш,“Қанджуххори (sorghum saacchartum) навларининг технологик хусусиятларини бахолаш ва биэтанол олиш усулларини илмий асослаш. дис Тошкент 2019 йил

6. Н.Ш.Муминов - Технология пектиновых и сахаристых веществ на основе хлопковой створки и стеблей сахарного сорго Ташкент 1998

7. Р.Мирзаев "Ширин жўхорини қайта ишлаб чорвачиликда фойдаланиш истиқболлари" Агроилм- ўзбекистон қишлоқ ва сув хўжалиги. № $1\{64\}$.2020. Б. 25-26.

8. АзизовА., Сулаймонов Б. Chemical composition of canned sweet corn juice. // linternational journal for innovative research in multidisciplinary field. Volume

9. П. Крылов Технология производства продукции пчеловодства по законам природного стандарта / А.Г. Маннапов и др. - Москва: Мир, 2016. - 192 C.

10. Пчеловодство. - М.: Советская Энциклопедия, 1991. - 512 C.

11. Пчёлы. Разведение и содержание. - М.: Рипол Классик, Владис, 2013. - 209 с.

12. С.В. Морибель Чем, когда и каким образом нужно кормить пчёл / С.В. Морибель. - М.: ЁЁ Медиа, 2006. - 593 с. 
The American Journal of Agriculture and Biomedical Engineering (ISSN - 2689-1018)

VOLUME 04 ISSUE 01 Pages: 5-12

SJIF IMPACT FACTOR (2020: 5. 34) (2021: 5. 554)

OCLC - 1121105746 METADATA IF - 7.125

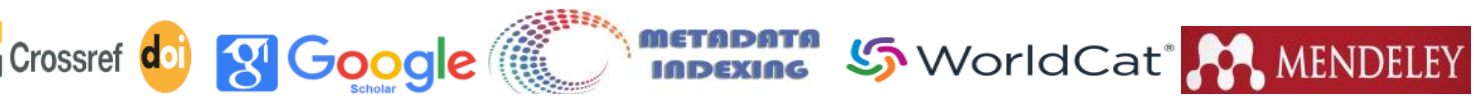

13. https/WWWtadvizer/ru index

14. podrobno.uz

15. https://www.beepods.com/its-time-to-feed-

those-bees/ 